\title{
Wholesale Coalition in a Sole Candidate Election: The Case of the 2018 Tangerang Regent Election
}

\author{
Khoerun Nisa Fadillah ${ }^{1}$, Panji Anugrah Permana ${ }^{2}$ \\ \{khoerun.nisa@ui.ac.id, panji.anugrah@gmail.com\} \\ Universitas Indonesia, Indonesia \\ Universitas Indonesia, Indonesia ${ }^{2}$
}

\begin{abstract}
This study aims to explain why and how all political parties build a coalition to support the incumbent as the sole candidate in a local election. Specifically, it illuminates the case of the 2018 Tangerang local election, which provides rich data on both aspects of the wholesale coalition and the sole candidate. The article argues that the decision of each political party in the coalition to support the incumbent was a strategic choice. The parties considered that the incumbent had more political power and better chance at winning the election than the other candidates. Furthermore, the coalition's decision was reinforced by the incumbent through side-payment politics in the form of policy promises, decision promises, emotional satisfaction, material benefits, and coattail effects. When agreements with the local party leader failed, the incumbent built an agreement directly with the central board of parties. The central board of parties has the authority to decide the nomination of the candidate, and the local leader inevitably had to accept the decision.
\end{abstract}

Keywords: Coalition, Sole Candidate, Incumbent, Strategic Choice.

\section{Introduction}

The emergence of sole candidate local elections increased after the Decision of the Constitutional Court of the Republic of Indonesia in 2015, which regulates the occurrence of sole candidacy (i.e., only one pair of candidates). In 2015, three out of 269 regional elections had a sole candidate. This number increased to nine out of 101 elections in 2017 and then to 16 out of 171 elections in 2018.

Research findings based on the 2015 local elections in Blitar, Tasikmalaya, and Timor Tengah Utara indicate that the emergence of sole candidate elections was triggered by parties' resistance to the ruling party and led to the postponement of the elections [1][2]. Likewise (2017), sole candidate elections in Pati and Jayapura show resistance or pre-election competition among political elites [3]. However, in 2018, neither resistance nor competition among parties resulted in the emergence of sole candidacy election. Rather, agreements among parties to win the elections without an opponent can be seen as the primary causal factor. For example, in 13 of 16 sole candidate elections, such as the local election in Tangerang District, the sole candidates were supported by all parties that had seats in the local parliament (DPRD).

In 2015-2017, the pattern of coalition among parties in sole candidate elections varied by region. In Timor Tengah Utara, the incumbent sole candidate was only supported by one political party, PDIP, while other parties did not support the pair. In other cases, such as in Blitar 
and Tasikmalaya, several political parties provided their electoral tickets to the incumbent sole candidate. Nevertheless, almost all political parties in several regions supported the sole candidate, as in Tebing Tinggi, Pati, Buton, Landak, Central Maluku, Tambrauw, Sorong, and Jayapura. Nevertheless, this big coalition left room for other candidates to emerge. West Tulang Bawang was the only region in which the sole candidate was supported by a coalition of all parties. Then, in the 2018 local elections, almost all the coalitions were formed by all parliamentary parties. This closed the chance for any other candidates to stand for the election through a political party's nomination.

Some observers believed that the emergence of sole candidacy in local elections was driven by the failure of party recruitment to provide alternative candidates for local leaders [4]. However, this observation is not entirely true regarding the Tangerang local election in 2018. The emergence of a sole candidate in Tangerang was not caused by a lack of parties' members who were willing to run. Rather, it was caused by the decision of the central board of parties. Many party members were hit by the demand for ownership of financial resources when they wanted recommendations from the central board. In the end, parties in the regions had to agree with the center's decision to support a sole candidate. Jayusman from the Gerindra Party and Dedi Sutardi from the Democrat Party were examples of party members who did not gain support from their center-level party to stand for the election.

All parliamentary parties in Tangerang built a coalition for the incumbent sole candidate: Golkar Party (7 seats), PDIP (7 seats), PPP (6 seats), Democrat Party (6 seats), Gerindra Party (5 seats), Nasdem Party (4 seats), PKB (4 seats), PAN (4 seats), Hanura Party (3 seats), PKS (2 seats), PBB (1 seat), and PKPI (1 seat). On paper, the election could have had a maximum of five pairs of candidates with party support, given the composition of the seats as well as the minimum requirement. The nomination threshold for the Tangerang election was 10 seats or $20 \%$ of the total 50 seats in the DPRD. In previous elections, parties promoted their members by building coalitions with other parties. In 2008, the coalition of Golkar Party, PDIP, PAN, and PPP supported the pair of Ismet Iskandar and Rano Karno; Democrat Party and PKB supported Usamah Hisyam and Habib Al Alwi Alhusaini; and PPNUI, PBB, PBR, PKPB, PKS, and PSI backed Jazuli Juwaini and Airin Rachmy Diani. In the subsequent election in 2012, the coalition of the Golkar Party, Hanura, Gerindra, PKS, PKB, PBR, and PBB supported Ahmed Zaki Iskandar and Hermansyah; the Democrat Party backed Ahmad Subadri and Aufar Hutapea; the PPP, PPNUI, PKPB, and PDP coalition supported Aden Abdul Khalik and Suryana; and the PDIP and PAN endorsed Ahmad Suwandi and Muhlis. The two elections were won by the pair of candidates backed by the Golkar Party, namely, Ismet Iskandar and Rano Karno and Ahmed Zaki Iskandar and Hermansyah, respectively. Ahmed Zaki Iskandar, who had been the sole candidate for the 2018 election, is the son of the two-period former regent, Ismet Iskandar (2003-2013).

Prior to the election, local parties in Tangerang had many potential and prospective members who might have run. For instance, the Golkar Party had six members who joined the party selection: Ahmed Zaki Iskandar, Mad Romli, Taufik, H. Zaenul, Andi Achmad Dara, and H. Zaini. PDIP had four members (Topari, Indah, Dasta, and Treasurer DPC PDIP-Central Java), and the Democrat Party had two members (Dedi Sutardi and Aida Hubaedah). Gerindra Party had one prospective candidate (Jayusman), as did PKB (Tommy Kurniawan). PAN also had a member (Sri Panggung Lestari). These five parties had built an initial coalition with some other parties to fulfil the nomination seat threshold. However, in the final stage, the party coalition supported the incumbent as the only candidate in the election.

This raises the question: why did all parties support the incumbent as a sole candidate and how did the pattern of the coalition form? Previous studies have somewhat neglected to examine 
party coalitions and the process of coalition building in sole candidate elections. This article seeks to fill the gap in the existing literature by answering the question above, focusing on the 2018 Tangerang Regent Election.

\section{Theoretical Review}

Previous studies on coalitions of political parties in Indonesia mostly examine the causal factors influencing coalition formation. The literature recognizes different predictors for coalition formation, ranging from material benefit motives to office-seeking reasoning, policyseeking objective, and cartel-seeking target [5][6][7][8][9][10]. Meanwhile, research on the emergence of sole candidate elections in Indonesia shows that they are driven by several causal factors such as cartel politics, the failure of recruitment functions of political parties, incumbent superiority, fear of potential opponents, political oligarchy and unequal elite competition, and the strategic actions of political actors [1][11][12][4][13][2]. It is difficult to find research on the tendency of political parties to build big coalitions in sole candidate elections. Yuristianti (2018) [14] revealed that political parties had a pragmatic attitude toward coalition formation to support the pair of a sole candidate.

To answer the research questions, this article operationalizes Collier and Norden's (1991) [15] analytical frameworks of strategic choice and Riker's (1962) coalition building [16]. Strategic choice theory explains the reasons behind actors' decisions to build a coalition. Actors' choices are influenced by the context related to the identification of which actors are pro or contra to the coalition and the threshold in forming coalitions. Besides, actors' decisions take into account strategic calculations, subjective probabilities, and costs and benefits. Both choice and strategy are determined by political communication through interactions of different actors to produce political decisions.

The dynamic model of coalition building can help explain how all political parties build a coalition for a sole candidate. This theory will identify who the leader and the follower are in the coalition building of sole candidate supporter parties. What is the interaction between the two? How do the leaders attract followers, whether through side payments (in the form of threats of retaliation, policy promises, decision promises, emotional satisfaction, or objects that are calculated with the value of money) or not? If applicable, what are the side payments?

\section{Research Method}

This study used a qualitative approach with a case study method. The primary data sources were in-depth interviews with all chairmen and several parliamentary party managers in Tangerang. Secondary data were also collected from newspapers, magazines, legal documents, academic literature, etc.

\section{Results and Discussion}

\subsection{Strategic choices of the coalition actors}


Party decisions on the 2018 Tangerang election were based on the surrounding context, which related to the identification of actors and the threshold of coalition formation. There were five political parties who initially resisted the emergence of a sole candidate pair: PKS, Gerindra Party, Democrat Party, PAN, and PKB. They initially rejected the candidacy of Ahmed Zaki Iskandar and Mad Romli, who are both Golkar Party members. The existence of this opposition shows the dynamics of the parties' resistance to the incumbent. The threshold for coalition formation in proposing candidates influenced actors' choices in coalition development. Each party had to build a coalition with the other party or parties in order to comply with the minimum requirement. However, the incumbent disregarded the minimum threshold and undertook all parliamentary parties in order to win the nomination. In this case, the incumbent sought to gather the support of all political parties to clinch the victory. Furthermore, the incumbent revealed that he appealed to all parties as an effort to show his good ethics and intentions. It was also done in anticipation of the shortage of seats in the Golkar Party, as simultaneous candidate selections in all parties were registered by many non-incumbents (interview with Ahmed Zaki Iskandar, Tangerang, March 22, 2019).

This situation encouraged the parties to develop their own strategies based on objective calculations and subjective considerations. Some parties had subjective amiability due to their personal closeness to the incumbent, such as PDIP, Nasdem Party, PAN, and PPP. In the end, all actors had to make a pragmatic choice about whether to join the incumbent coalition or not, taking into account the costs and benefits as well as the predictions concerning the chances of winning the election or being defeated.

Supported by strong incumbency political power and good political communication skills, as well as the prediction of his electability, the incumbent showed his strength to the parties objectively and subjectively. Ultimately, all the parties decided to join the coalition. Thus, the coalition building was based on parties' strategic choices, i.e., the parties predicted that it would be difficult to rival the electability of the incumbent. The risk of major losses and political costs would have been greater if they had fought against him. Thus, supporting the incumbent was a way for the parties to reduce political cost expenditure. Moreover, the incumbent had a good track record and communication skills that appealed to PKS, PDIP, Democrat Party, PAN, Gerindra Party, PPP, PBB, PKPI, Nasdem Party, PKB, and Golkar Party. For parties that had only one seat, like $\mathrm{PBB}$, the incumbent's ability to convey the right attitude was appreciated because it built emotional connections. This was expressed by the local leader of PBB as follows:

During the two months of registration, only Mr. Zaki registered... Just like that, Mr. Zaki has built an emotional connection, and we appreciate it. Why (we) support the incumbent, because the development in Tangerang is good. Incumbent has good hospitality and good emotional character, still young, and trustworthy in continuing the development in Tangerang. The benefit (for us to support him) is just happy, to become his partner in parliament. (interview with Kamil Herdiana, Tangerang, March 10, 2019)

PPP considered that the incumbent had a proven track record in line with their desire because of his attention to religious issues. This was articulated by the local leader of PPP as follows:

The Regent's track record in the first period showed his concern with religious affairs. There was a Sanitren Program, sanitation in Islamic boarding schools. In the Kosambi region, prostitution was closed. These (programs) were attractive to us. (interview with Naziel Fikri, Tangerang, March 9, 2019)

The parties expected that they would not need to spend much money to support the incumbent. In Golkar Party's opinion, as the party of the incumbent, having a big coalition and 
a sole candidate was a cost-effective condition. The head of Hanura Party discussed the political costs of having multiple candidates. In the previous election in 2012, when he was competing as a regent candidate supported by the Democrat Party, the campaign cost was Rp30 billion (interview with Ahmad Subadri, Tangerang, April 6, 2019). It was a very large amount of money compared to the campaign costs in 2018, which were only Rp642.608,983 (Report on the Receiving and Expenditures of Campaign Funds for Participants in the Regent and Deputy Regent of Tangerang Regency on behalf of Ahmed Zaki Iskandar and H. Mad Romli and Independent Asurans Reports from KPU Tangerang Regency).

Some political parties had potential candidates to run in the election, while others did not. Although there were internal members who registered, the Democrat Party decided to join the incumbent's large coalition due to the risk of being defeated if they fought against him. PAN had previously considered building a rival coalition, but finally decided to support the incumbent. Some other parties had no members to contest the incumbent. The lack of a candidate among these parties was mostly related to the lack of financial capacity for electoral campaign costs. Other parties such as Hanura faced a different problem: the prospective candidates of this party were mostly legislators. In electoral law, legislative members have to resign once they run for the local executive election. Prospective candidates did not want to give up their current positions, especially if they had only a slim chance of winning against the incumbent.

Furthermore, some party politicians looked forward to other political events such as the legislative election in 2019, rather than local elections. They decided it would be better to devote their energy to the former rather than the latter, where they expected to gain a positive coattail effect by supporting the incumbent. This consideration had occurred to PKS, PDIP, and the Democrat Party, which had a pragmatic concern facing the 2019 legislative election. Rather than wasting energy and funds fighting the incumbent, they preferred to save their resources for the 2019 legislative election.

\subsection{The pattern of political parties' coalition building for the sole candidate}

The incumbent was not the only candidate who communicated with political parties. Several prospective candidates tried to establish relationships with certain parties, as shown in the cases of Dedi Sutardi with Democrat Party and Jayusman with Gerindra Party. This initial coalition building among candidates even led to political tensions between party followers of the incumbent and other prospective candidates.

There were five contested political parties at the initial stage: PKS, Gerindra, Democrats, PAN, and PKB. At first, these political parties opposed the incumbent coalition, while the incumbent put these parties as his main concern. PAN and PKB agreed to join the incumbent coalition after they were offered side payments in the form of policy promises at the regional level. In contrast to PAN and PKB, regional party elites of Gerindra and Democrat Party could not be invited to join the coalition due to their resistance to the incumbent camp. However, the incumbent employed a political lobby to the central party leaders. As a result, both political parties issued a formal recommendation for the incumbent. The agreement, however, raised speculation about the possibility that side payments had been given in the form of material benefits (interview with Dedi Sutardi, Tangerang, March 6, 2019; interview with Rijcki Gilang Sumantri, Tangerang, March 4, 2019). Both local party leaders could not refuse and had to accept the central party decision to assist the incumbent's nomination. Finally, PKS was realistic enough in responding to the situation and joined the coalition, receiving side payments in the form of a coattail effect. This was revealed by the local leader of PKS, who said, "A coattail 
effect was with PKS when supporting Mr. Zaki" (interview with Wisnu Yudhamukti, Tangerang, March 4, 2019). In the end, the incumbent was able to build agreements with all five parties through side payments.

The other parties were successfully invited to join the coalition with side payments that were adjusted according to each one's political power. Parties with strong political power, such as PPP (more than five seats), received side payments in the form of policy promises as well as the indication of material payments. This was revealed by the local leader of PPP as follows:

The most important thing is the political contract. The first is when he becomes Regent, is he able and willing to support PPP? Secondly, because the PPP is an Islamic Party, the candidate promoted by PPP must care and pay attention to religious issues. That is actually the most fundamental concern of PPP in supporting candidates. (Interview with Naziel Fikri, Tangerang, 9 March 2019)

Other parties such as Hanura Party and Nasdem Party (more than two seats) received side payments in the form of government policies or projects. Included in this form of side-payment was a pay-off for strategic positions for party members. Parties that lacked sufficient political power because they had only one seat, such as PKPI and PBB, expected electoral benefits for the consecutive legislative election through coattail effects and emotional satisfaction because they had been invited by the incumbent.

The PDIP had its own special position. Even though the party had strong political power with seven seats, the side-payment offered was only a coattail effect. The close relationship between the party's local head and the incumbent was perhaps another reason for the party's support (interview with Irvansyah, Jakarta, March 1, 2019).

From the above explanation, it is clear that the incumbent played an important role in his coalition building with political parties.

\section{Conclusion}

The decision of all parties to build a coalition for the incumbent in the sole candidate election was the result of the parties' strategic choices. The parties recognized the incumbent's strong political and economic resources as well as his strong chance at winning the election. In addition, they considered he was a good person with a friendly demeanor. The way he communicated made the party leaders feel more comfortable supporting him over the other candidates. The parties calculated that the political costs would not be greater than the benefits they expected to be receiving from the incumbent's nomination.

The formation of the coalition by the incumbent shows that he sought not only to increase his chance of victory, but also to block the emergence of other candidates. Two strong challengers, Jayusman and Dedi Sutardi, who already had political support from their own local parties, ultimately failed to gain the nomination. Instead, the incumbent bypassed the local party decision by appealing directly to the central party leader to win the party ticket. The local parties could not refuse and had to accept the decision. Thus, the sole candidate election in Tangerang demonstrates the powerlessness of local parties to overcome the central party's power.

\section{References}

[1] F. N. Eristyawan, "Demokrasi dalam Pusaran Politik Kartel: Studi Kasus Calon Tunggal dalam Pilkada Serentak Kabupaten Blitar Tahun 2015," Tesis Univ. Airlangga, 2017.

[2] B. Dalupe, "Struktur Arena dan Tindakan Strategis Aktor dalam Pilkada Serentak (Studi Kasus 
Mundurnya Kandidat Penantang dari Proses Pilkada Kabupaten Timor Tengah Utara Tahun 2015)," Tesis Univ. Indones., 2019.

[3] dan N. Lay, Cornelis, \& Hasrul Hanif, \& Ridwan, "The Rise of Uncontested Elections in Indonesia: Case Study of Pati and Jayapura," Contemp. Southeast Asia, vol. 39, no. 3, 2017.

[4] W. U. P. Danny, "Analisis Rekrutmen dan Kaderisasi Partai Politik Pada Fenomena Calon Tunggal Petahana: Studi Kasus Pilkada Kabupaten Pati 2017.” Faculty of Social and Political Sciences, 2018.

[5] S. B. E. Wardani, "Koalisi partai politik dalam pemilihan kepala daerah secara langsung: Kasus pilkada Provinsi Banten tahun 2006." FISIP-UI, 2007.

[6] N. A. T. U. Hakim, "Strategi Pembentukan Koalisi Pasangan Calon Irna Narulita-Tanto Warsono Arban dalam Pemilukada Kabupaten Pandeglang Tahun 2015,” Tesis Univ. Indones., 2016.

[7] S. Yahya, "Institusi politik dan pilkada: studi atas koalisi partai pendukung Airin Rachmi Diany dan Benyamin Davnie pada Pilkada Kota Tangsel 2015.” Jakarta: Fakultas Ilmu Sosial dan Ilmu Politik UIN Syarif Hidayatullah, 2016.

[8] M. Nurhasim, "Koalisi Nano-Nano Pilkada 2018: Sebuah Analisis," J. Penelit. Polit., vol. 15, no. 2, pp. 129-142, 2018.

[9] I. Putri, "Analisis Motif Koalisi Partai Politik dalam Menghadapi Pemilihan Gubernur Lampung Tahun 2018 (Studi pada Koalisi Partai NasDem, PKS dan Hanura Provinsi Lampung),” 2018.

[10] dan S. K. D. Mahpudin, Abdul Hamid, "Dinamika Koalisi Partai Politik dalam Pencalonan Kepala Daerah pada Pilkada Banten 2017," Pros. Semin. Nas. Prodi Ilmu Pemerintah. 2018, 2018.

[11] C. Lay, H. Hanif, and N. Rohman, "The Rise of Uncontested Elections in Indonesia: Case Studies of Pati and Jayapura," Contemp. Southeast Asia, pp. 427-448, 2017.

[12] W. Sobari, "Blater, from Affinity to Tyranny? The Phenomenon of Sole Candidate in the 2015 Local Election in Blitar Regency, Indonesia," in Third International Conference on Social and Political Sciences (ICSPS 2017), 2017.

[13] H. J. Nge, “Oligarki Partai Politik dalam Rekrutmen Calon Kepala Daerah,” J. Acad. Praja, vol. 1, no. 1, pp. 59-84, 2018.

[14] S. Yuristianti, "Fenomena Calon Tunggal Dalam Pemilihan Umum Kepala Daerah Kabupaten Pati 2017 (Studi Kasus: Sistem Rekrutmen Calon Oleh Partai Politik),” J. Polit. Gov. Stud., vol. 7, no. 2, pp. 61-70, 2018.

[15] D. Collier and D. L. Norden, "Strategic choice models of political change in Latin America." JSTOR, 1992.

[16] W. H. Riker, The theory of political coalitions. Yale University Press, 1962. 